\title{
Corrigendum
}

\section{Hotspot autoimmune $T$ cell receptor binding underlies pathogen and insulin peptide cross-reactivity}

David K. Cole, Anna M. Bulek, Garry Dolton, Andrea J. Schauenberg, Barbara Szomolay, William Rittase, Andrew Trimby, Prithiviraj Jothikumar, Anna Fuller, Ania Skowera, Jamie Rossjohn, Cheng Zhu, John J. Miles, Mark Peakman, Linda Wooldridge, Pierre J. Rizkallah, and Andrew K. Sewell

Original citation: J Clin Invest. 2016;126(6):2191-2204. doi:10.1172/JCI85679.

Citation for this corrigendum: J Clin Invest. 2016;126(9):3626. doi:10.1172/JCI89919.

The original publication incorrectly stated that a peptide with the sequence YQFGPDFPTA was used as one of the altered peptide ligands. The correct sequence is YQFGPDFPIA. The online version of the article has been updated with the correct sequence. This error appeared in the following parts of the manuscript:

Methods, "Crystal structure determination"

Figure $1 \mathrm{~B}$ and legend

Figure 2 legend

Figure 5 legend

Figure $6 \mathrm{G}$ and legend

Figure 7 legend

Figure 8 legend

Table 1

The authors regret the error.

\section{Corrigendum}

Transcription factor TBX4 regulates myofibroblast accumulation and lung fibrosis

Ting Xie, Jiurong Liang, Ningshan Liu, Caijuan Huan, Yanli Zhang, Weijia Liu, Maya Kumar, Rui Xiao, Jeanine D’Armiento, Daniel Metzger, Pierre Chambon, Virginia E. Papaioannou, Barry R. Stripp, Dianhua Jiang, and Paul W. Noble

Original citation: J Clin Invest. 2016;126(8):3063-3079. doi:10.1172/JCI85328.

Citation for this corrigendum: J Clin Invest. 2016;126(9):3626. doi:10.1172/JCI89968.

The tamoxifen doses in the original publication were incorrect. The online version of the article has been updated with the correct doses, which are given below:

Figure 4 legend, $0.2 \mathrm{mg} / \mathrm{g} /$ dose and $0.1 \mathrm{mg} / \mathrm{g} / \mathrm{dose}$

Figure 5 legend, $0.2 \mathrm{mg} / \mathrm{g} / \mathrm{dose}$

Figure 7 legend, $0.2 \mathrm{mg} / \mathrm{g} /$ injection

Figure 8 legend, $0.2 \mathrm{mg} / \mathrm{g} /$ injection

Figure 9 legend, $0.2 \mathrm{mg} / \mathrm{g} /$ injection

Methods, second paragraph, $0.1 \mathrm{mg} / \mathrm{g}$ and $0.2 \mathrm{mg} / \mathrm{g}$

Supplemental Figure 13, $0.2 \mathrm{mg} / \mathrm{g}$

The authors regret the errors. 